\title{
ISOLASI LISOZIM ALBUMIN TELUR AYAM RAS DENGAN METODE KROMATOGRAFI PENUKAR ION
}

\author{
[Isolation of Lysozyme from Hen Egg Albumin Using lon Exchange Chromatography]
}

\author{
${\text { Zakiah } \text { Wulandari }^{1) *} \text {, Dedi Fardiaz }}^{2)}$, Maggy T. Suhartono ${ }^{2)}$, Nancy Dewi Yuliana ${ }^{2)}$, dan \\ Cahyo Budiman ${ }^{1)}$ \\ 1) Departemen Ilmu Produksi dan Teknologi Peternakan, Fakultas Peternakan, Institut Pertanian Bogor, Bogor \\ 2) Departemen IImu dan Teknologi Pangan, Fakultas Teknologi Pertanian, Institut Pertanian Bogor, Bogor
}

Diterima 22 September 2017 / Disetujui 12 Oktober 2018

\begin{abstract}
Lysozyme is one of the proteins found in hen egg albumin. Besides known as antimicrobial agents, lysozyme hydrolysis products can also function as antioxidants and as angiotensin converting enzyme (ACE) inhibitors. The lysozyme is also known to have lysine and arginine that can give a sweet taste. The research aimed to isolate lysozyme from commercial laying hen eggs. The isolation and purification of the eggs lysozyme was done by preparative and analytical separation technique using cation exchange resins. The preparative separation was carried out by centrifugation of a large sample size of $205 \mathrm{~g}$ by centrifugation, while the analytical separation only used only $3.16 \mathrm{~g}$ sample with a column measuring $13 \mathrm{~cm}$ in length and $3 \mathrm{~cm}$ in diameter. The number of samples isolated by preparative separation is greater than that with analytical method. The preparative separation was conducted in order to obtain the pure isolated lysozyme in higherquantity for further testing purposes. The purity of the isolated lysozyme from preparative separation was $68.62 \%$ and the purity of isolated lysozyme from analytical separation was $63.03 \%$.
\end{abstract}

Keywords: chromatography cation exchange method, commercial laying hens, lysozyme

\begin{abstract}
ABSTRAK
Lisozim adalah salah satu jenis protein yang terdapat pada albumin telur unggas. Selain dikenal sebagai antimikrobia, hasil hidrolisis lisozim juga dapat berfungsi sebagai antioksidan dan sebagai angiotensin converting enzyme (ACE) inhibitor. Lisozim juga diketahui memiliki gugus lisin dan arginin yang dapat memberikan rasa manis. Tujuan penelitian adalah isolasi lisozim dari putih telur ayam ras. Isolasi dan purifikasi lis ozim dilakukan dengan dua metode, yaitu metode pemisahan s ecara preparatif dan analitik. Pemisahan preparatif dilakukan dengan jumlah sampel yang besar mencapai $205 \mathrm{~g}$ dengan sentrifugasi, sedangkan pemisahan secara analitik sampel yang dipisahkan hanya 3,16 g dengan kolom berukuran panjang $13 \mathrm{~cm}$ dengan diameter $3 \mathrm{~cm}$. Jumlah sampel yang diisolasi dengan pemisahan preparatif lebih besar dibandingkan secara analitik. Pemisahan dengan metode preparatif dilakukan untuk mendapatkan lisozim terisolasi murni dalam jumlah yang lebih besar untuk tujuan pengujian lebih lanjut. Ke murnian lis ozim terisolasi dari pemisahan preparatif adalah $68,62 \%$ dan kemurnian lisozim terisolasi dari pemisahan analitik adalah $63,03 \%$.
\end{abstract}

Kata kunci: lisozim, metode kromatografi penukar kation, telur ayam ras

\section{PENDAHULUAN}

Telur adalah pangan asal ternak yang merupakan salah satu pangan sumber protein. Menurut LiChan et al. (2014) putih telur merupakan bagian dari telur yang mengandung 9,7-10,6\% protein, $80 \%$ air, $0,4-0,9 \%$ karbohidrat, $0,03 \%$ lemak dan $0,5 \%$ mineral. Protein putih telur tersusun atas beberapa macam protein, antara lain adalah ovalbumin (54\%),

*Penulis Korespondensi:

E-mail: zakiahw ulandari75@gmail.com ovotransferin (12\%), ovomucoid (11\%), ovomucin $(3,5 \%)$ dan lisozim $(3,4 \%)$. Telur memiliki nilai biologi tertinggi yaitu 100 dibandingkan dengan daging dengan nilai biologi 84 dan susu 91, karena telur jika dibuahi akan menjadi individu hewan baru yang membutuhkan komponen biologi yang prima.

Menurut Direktorat Jenderal Peternakan dan Kesehatan Hewan (2017) produksi telur ayam ras petelur pada tahun 2016 sebesar 1,485 juta ton, nilai ini mengalami kenaikan sebesar 7,6\% dibandingkan tahun 2015. Indonesia telah mencapai swasembada pangan untuk telur. Tercapainya swasembada telur 
memberikan peluang untuk meningkatkan nilai tambah telur dengan produksi komponen bioaktif telur. Salah satu komponen bioaktif yang memiliki banyak fungsi adalah lisozim. Lisozim sebagai antimikrobia, telah dinyatakan aman digunakan dalam bahan pangan. Kemampuan lisozim sebagai antimikrobia ditandai dengan sifatnya yang mampu melisis dinding sel bakteri. Lisis terjadi karena terurainya ikatan $\alpha$ 1,4 antara $\mathrm{N}$-asetilmuramic acid dengan $\mathrm{N}$-acetylglucosamine (NAG) pada peptidoglikan (murein) di dinding sel bakteri (Thammasirirak, 2010). Kekhasan lisis ini menyebabkan lisozim juga dikenal sebagai muramidase atau $\mathrm{N}$-acetylmuramic-hydrolase.

Selain dikenal sebagai antimikrobia, hasil hidrolisis lisozim juga dapat berfungsi sebagai antioksidan (Yazdi et al., 2012a; Rao et al., 2012) dan juga angiotensin converting enzyme (ACE) inhibitor (Asoodeh et al., 2012; Yazdi et al., 2012b). Lisozim juga diketahui memiliki gugus lisin dan arginin yang dapat memberikan rasa manis (Ide et al., 2009). Isolasi dan purifikasi lisozim dari putih telur telah banyak dilakukan dengan berbagai macam metode. Lisozim telah berhasil diisolasi dari tanaman dan produk perikanan (Ercan et al., 2014; Forabosco et al., 2013). Isolasi lisozim dari telur relatif lebih mudah jika dibandingkan dengan isolasi dari sumber lainnya. Lisozim dapat diisolasi menggunakan amonium sulfat dengan karakteristik protein yang belum optimal. Beberapa metode yang dikembangkan sampai saat ini masih terbatas pada skala laboratorium. Menurut Safarik et al. (2007) isolasi lisozim dapat dilakukan dengan berbagai macam metode, yaitu kromatografi penukar ion (Li et al., 2017) kromatografi afinitas (Ding et al., 2014), utrafiltrasi (Datta et al., 2009), Polietilen Glikol (PEG) (Geng et al., 2012; Depamede et al., 2012). Abeyrathne et al. (2014) mengembangkan metode isolasi dan purifikasi lisozim untuk skala pilot plant berdasarkan prinsip pertukaran kation menggunakan resin penukar kation secara preparatif. Pada penelitian tersebut dihasilkan rendemen lisozim sebesar $89,72 \%$ dengan tingkat kemurnian sebesar $96,5 \%$. Pada penelitian ini dilakukan juga dengan metode analitik sebagai pembanding. Metode analitik adalah metode isolasi dengan jumlah sampel yang lebih kecil dibandingkan dengan metode preparatif. Penelitian ini dilakukan untuk melihat tingkat kemurnian pada tiap tahapan atau fraksi, pada penelitian Abeyrathne et al. (2014) tingkat kemurnian tiap tahapan tidak dijelaskan.

Penelitian ini dilakukan dengan tujuan mengisolasi lisozim dari telur ayam ras dengan menggunakan resin penukar kation secara preparatif dan analitik dan membandingkan hasil dua metode tersebut. Metode preparatif diharapkan sebagai dasar untuk produksi lisozim dari telur ayam ras skala pilot plant dan skala industri.

\section{BAHAN DAN METODE}

\section{Bahan}

Telur ayam ras komersial diperoleh dari kandang program Diploma IPB, resin amberlite FPC 3500 (Across, USA) dan Marker PageRuler Unstained Protein Ladder Thermo Scientific, USA (10$200 \mathrm{kDa})$.

\section{Persiapan sampel}

Telur dipilih berdasarkan kualitasnya yaitu kerabang dan isi telur bersih dari noda darah, telur tidak berisi embrio, dan viskositas isi telur tinggi. Telur dicuci dengan air hangat $\left(35-40^{\circ} \mathrm{C}\right)$ kemudian ditiriskan. Selanjutnya telur dipecah, bagian kuning telur dipisahkan dari bagian putih telur, dan bagian putih telur digunakan untuk isolasi lisozim.

\section{Penyiapan resin amberlite FPC 3500 sebagai penukar kation}

Resin FPC 3500 diekulibrasi dengan menggunakan $\mathrm{NaOH} 2 \mathrm{~N}$ (Merck, Jerman) sampai mencapai pH 9,3 (Abeyrathne et al., 2014).

\section{Isolasi preparatif lisozim}

Isolasi preparatif lisozim menggunakan metode menurut Abeyrathne et al. (2014). Sebanyak $205 \mathrm{~g}$ putih telur dilarutkan dalam akuades steril dengan perbandingan volume 1:1. Amberlite FPC 3500 ditambahkan ke dalam larutan putih telur dengan perbandingan 0,5 g amberlite FPC 3500 untuk setiap $10 \mathrm{~mL}$ larutan putih telur. Larutan diaduk dengan alat pengaduk (Thermo, USA) pada kecepatan terendah (100 rpm) selama satu malam pada suhu $4^{\circ} \mathrm{C}$. Tahapan selanjutnya adalah sentrifuse (Himac CR 21G, Jepang) $3400 \mathrm{~g}$ selama 20 menit pada suhu $4^{\circ} \mathrm{C}$. Optimasi pengikatan lisozim oleh resin amberlite FPC 3500, lisozim dan resin diinkubasi pada $\mathrm{pH} 8$ selama 12 jam pada suhu $4^{\circ} \mathrm{C}$. Resin dicuci tiga kali dengan akuades steril untuk menghilangkan semua protein selain lisozim yang ada dalam resin, kemudian resin dikondisikan dalam bufer $0,1 \mathrm{M}$ glisin- $\mathrm{NaOH}$ (Merck, Jerman) $\mathrm{pH}$ 8. Untuk melepaskan lisozim yang terikat pada resin, ditambahkan dengan $\mathrm{NaCl}$ (Merck, Jerman) 0,5 M ke dalam bufer 0,1 M glisin- $\mathrm{NaOH} \mathrm{pH}$ 8. Selanjutnya resin dikondisikan pada $\mathrm{pH} 9$ dan $\mathrm{pH} 10$ dengan penambahan $\mathrm{NaCl}$ 0,5 M untuk melepaskan lisozim. Absorbansi hasil pencucian dan isolasi diukur dengan spektrofotometer UV Vis (Agilent model 8453, Jerman) pada panjang gelombang $280 \mathrm{~nm}$.

\section{Rendemen}

Rendemen dihitung berdasarkan rumus sebagai berikut:

Rendemen $=\frac{\text { Konsentrasi protein } \times \text { volume protein }}{\text { konsentrasi protein pada telur } \times \text { konsentrasi lisozim } \times \text { berat sampel }}$ 


\section{Isolasi lisozim dengan metode analitik}

Isolasi lisozim dengan metode analitik yang dimodifikasi dari Abeyrathne et al. (2014). Sebanyak $3,16 \mathrm{~g}$ putih telur dilarutkan dalam akuades steril dengan perbandingan volume 1:10. Amberlite FPC 3500 yang telah diekulibrasi dimasukan ke dalam kolom berukuran panjang $13 \mathrm{~cm}$ dengan diameter 3 $\mathrm{cm}$. Kolom diekulibrasi dengan bufer $0,1 \mathrm{M}$ glisin$\mathrm{NaOH}$ pH 9,3. Sampel yang telah diencerkan dimasukkan ke dalam kolom kemudian dielusi dengan menggunakan bufer $0,1 \mathrm{M}$ glisin- $\mathrm{NaOH} \mathrm{pH}$ 9,3 dengan konsentrasi $\mathrm{NaCl}$ bertingkat 0,1 sampai dengan 0,5 M. Absorbansi hasil elusi diukur dengan spektrofotometer UV-Vis (Agilent model 8453, Jerman), pada panjang gelombang $280 \mathrm{~nm}$. Rendemen dihitung dengan membagi total protein masingmasing tahapan dibagi dengan total protein sampel.

\section{Pengukuran berat molekul}

Analisis pengukuran berat molekul menggunakan metode menurut Laemmli (1970). Gel elektroforesis SDS-PAGE dibuat dengan konsentrasi stacking gel $4 \%$ dan resolving gel $12 \%$. Formulasi bahan yang digunakan untuk pembuatan gel dapat dilihat pada Tabel 1 berikut. Sampel ditambahkan ke dalam bufer sampel dengan perbandingan 1:2 (v/v). Kemudian dipanaskan pada suhu $95^{\circ} \mathrm{C}$ selama 40 detik. Campuran sampel dan bufer dimasukkan ke dalam sumur gel elektroforesis dan elektroforesis dijalankan pada voltase 200 volt, $20 \mathrm{~mA}$ selama 20 menit, kemudian dengan voltase 300 volt, $40 \mathrm{~mA}$ sampai sampel turun di bawah marker. Marker yang digunakan adalah PageRuler Unstained Protein Ladder Thermo Scientific, USA (10-200 kDa). Setelah elektroforesis selesai, gel diwarnai dengan direndam dalam Comassie Brilliant Blue (CBB) (Merck, Jerman) selama 40 menit. Selanjutnya CBB dihilangkan dengan merendam gel dalam larutan penghilang warna selama 24-48 jam. Pola pemisahan protein dan kemurnian protein ditentukan berdasarkan densitas pita protein dengan menggunakan software imageJ 14,7 (Wayne NIH USA, 2017). Hasil software imageJ 14,7 akan menunjukkan luasan area masing-masing protein yang didapat berdasarkan ketebalan pita yang diperoleh dari elektroforesis SDS-PAGE.

\section{Konsentrasi protein terlarut}

Analisis konsentrasi protein terlarut menggunakan metode menurut Lowry (Lowry et al., 1951). Pereaksi yang digunakan adalah larutan tembaga sulfat $(50 \mathrm{~mL}$ pereaksi 1: natrium karbonat $2 \%$ dalam
$\mathrm{NaOH} 0,1 \mathrm{~N}$ dan $1 \mathrm{~mL}$ pereaksi 2: $\mathrm{CuSO}_{4}$ 0,5\% dalam NaK Tartrat 1\%) (Merck, Jerman), pereaksi Folin Ciocalteau (Sigma Aldrich,USA) dan larutan BSA (bovine serum albumin) (Sigma Aldrich, USA) sebagai larutan protein standar. Pembuatan kurva standar dibuat dengan tujuh konsentrasi BSA (0; 2,5; 5; 10 dan $25 \mathrm{ppm}$ ). BSA dilarutkan dalam akuades $4 \mathrm{~mL}$, kemudian ditambahkan $5,5 \mathrm{~mL}$ larutan tembaga sulfat dibiarkan selama 10-15 menit pada suhu ruang. Selanjutnya ke dalam campuran ditambahkan $0,5 \mathrm{~mL}$ pereaksi folin, dihomogenkan dan dibiarkan selama 30 menit sampai warna biru terbentuk. Absorbansi diukur pada panjang gelombang $650 \mathrm{~nm}$ dan diplotkan pada kurva standar sesuai dengan konsentrasi BSA. Sebanyak 0,1-1 mL sampel dipipet ke dalam tabung reaksi, selanjutnya sampel diberlakukan sama seperti kurva pada standar.

\section{HASIL DAN PEMBAHASAN}

\section{Hasil isolasi lisozim telur ayam ras dengan meto- de preparatif}

Isolasi dan purifikasi lisozim dengan kromatografi penukar ion telah dilakukan sebelumnya oleh Abeyrathne et al. $(2013,2014)$ menggunakan resin amberlite FPC 3500. Resin ini memiliki kemampuan mengikat lisozim yang lebih baik dibandingkan dengan carboxy methyl celullose (CMC). Hal ini diduga karena gugus karboksilat dari amberlite bersifat lebih asam dibandingkan dengan $\mathrm{CMC}$ sehingga bisa mengikat lisozim lebih kuat. Stabilitas resin amberlite FPC 3500 pada pH basa lebih tinggi dibandingkan dengan CMC. Bahkan, $\mathrm{pH}$ basa memungkinkan seluruh gugus karboksilat pada resin ini terionisasi dan mampu berikatan secara kuat dengan molekul lain dengan muatan yang berlawanan.

Pada penelitian ini, $\mathrm{pH}$ yang digunakan adalah pH 8,0. Ketika resin amberlite FPC 3500 diekulibrasi pada $\mathrm{pH}$ ini, diyakini gugus karboksilat pada resin ini mengalami deprotonasi yang mengakibatkan resin bermuatan negatif. Sementara, lisozim akan bermuatan positif pada $\mathrm{pH}$ 8,0 karena titik isoelektrik (pl) protein ini adalah 10,7. Perbedaan muatan antara lisozim dan resin memungkinkan kedua group tersebut berikatan secara ionik. Syarat awal kromatografi penukar ion terpenuhi pada kondisi tersebut. Sebanyak 13 protein yang ada di dalam putih telur, $11 \mathrm{di}$ antaranya memiliki pl di bawah 6,0. Protein-protein tersebut, secara teoritik, akan bermuatan sama dengan resin sehingga tidak akan berikatan.

Tabel 1. Komposisi bahan elektroforesis SDS-PAGE

\begin{tabular}{ccccccc}
\hline$\%$ Gel & $\begin{array}{c}\mathrm{H}_{2} \mathrm{O} \text { steril } \\
(\mathrm{mL})\end{array}$ & $\begin{array}{c}\text { Akrilamide } \\
(\mathrm{mL})\end{array}$ & $\begin{array}{c}\text { Gel Bufer } \\
(\mathrm{mL})\end{array}$ & $\begin{array}{c}10 \% \text { w/v SDS } \\
(\mathrm{mL})\end{array}$ & $\begin{array}{c}10 \% \text { APS } \\
(\mu \mathrm{L})\end{array}$ & $\begin{array}{c}\text { TEMED } \\
(\mu \mathrm{L})\end{array}$ \\
\hline $4 \%$-stacking gel & 6,1 & 1,3 & 2,5 & 0,1 & 50 & 10 \\
$12 \%$-resolving gel & 3,4 & 4,0 & 2,5 & 0,1 & 50 & 5 \\
\hline
\end{tabular}


Satu protein, avidin, memiliki pl yang dekat dengan lisozim ( $\mathrm{pl} 10,00$ ) yang memungkinkan avidin berkompetisi dengan lisozim saat berikatan dengan resin. Akan tetapi, ikatan avidin diyakini lebih lemah dibandingkan dengan lisozim karena pl avidin sedikit lebih rendah dibandingkan dengan lisozim (Li Chan et al., 2014; Naknukool et al., 2008). Selain itu, konsentrasi avidin dalam putih telur juga tidak sebanyak lisozim sehingga dari sisi mass transfer tidak akan begitu memengaruhi ikatan lisozim dengan resin. Atas dasar asumsi tersebut diyakini bahwa kondisi yang digunakan dalam purifikasi ini cukup selektif untuk isolasi target lisozim.

Hasil kromatogram isolasi lisozim secara preparatif dapat dilihat pada Gambar 1. Berdasarkan Gambar 1 terlihat jelas terjadi pola penurunan nilai absorbansi pada tahap pencucian dan meningkat kembali pada tahap isolasi. Hasil elektroforesis SDS Page isolasi lisozim albumin telur ayam ras secara preparatif dapat dilihat pada Gambar 2.

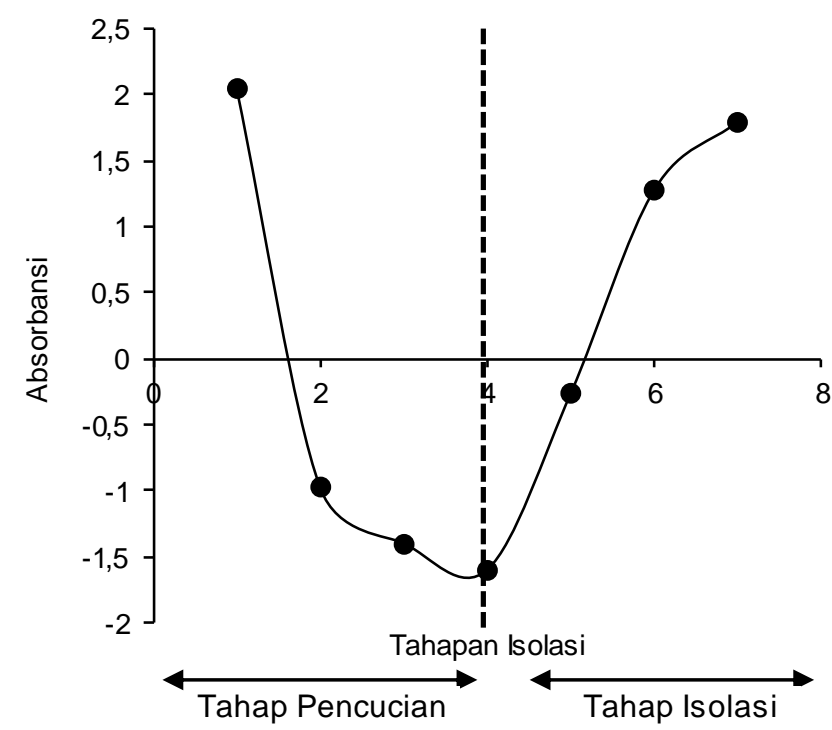

Gambar 1. Hasil isolasi lisozim secara preparatif dimonitor dengan pengukuran pada panjang gelombang $280 \mathrm{~nm}$

Konsentrasi protein terlarut pada tahap pencucian pertama dengan akuades steril tertinggi, adalah $1,61 \mathrm{mg} / \mathrm{mL}$, ini berarti sebagian besar protein telah tercuci oleh akuades steril tersebut. Hal ini sesuai dengan hasil elektroforesis SDS-PAGE (Gambar 3) yaitu terlihat pita yang tebal untuk protein albumin dengan persentase terbesar pada ovalbumin (54\%, $\mathrm{PI} 4,5, \mathrm{BM} 45 \mathrm{kD})$, ovotransferin $(12 \%, \mathrm{PI} 6, \mathrm{BM}$ $76 \mathrm{kD})$, ovomucoid (11\%, PI 4,1, BM $28 \mathrm{kD})$ dan ovomucin $(3,5 \%$, PI 4,5-5). Berdasarkan perhitungan dengan menggunakan perangkat lunak imageJ (Gambar 3) pada tahap pencucian pertama, protein dengan berat molekul $45 \mathrm{kD}$ yaitu ovalbumin mempunyai densitas (luas area) sebesar 1658,29 (13,3 kali dibandingkan dengan luas area lisozim). Pada tahap pencucian berikutnya protein dengan berat molekul yang sama mempunyai densitas sebesar 4721,3 (5,76 kali luas area lisozim). Nilai ini menunjukkan terjadi penurunan jumlah protein selain lisozim. Hasil ini sejalan dengan konsentrasi protein yang didapat sebesar $0,5 \mathrm{mg} / \mathrm{mL}$. Baik konsentrasi protein dan densitas menurun pada tahap pencucian ketiga sebesar $0,18 \mathrm{mg} / \mathrm{mL}$ dengan densitas 4243,18 dan tahap pencucian keempat sebesar 0,07 $\mathrm{mg} / \mathrm{mL}$ dengan densitas 1807,18.

Pada saat tahap isolasi lisozim menggunakan bufer $0,1 \mathrm{M}$ glisin- $\mathrm{NaOH}$ pH $80,5 \mathrm{M} \mathrm{NaCl}$ terlihat konsentrasi protein meningkat (Gambar 1 dan Tabel 2). Peningkatan konsentrasi ini menunjukkan lisozim yang terikat pada amberlite FPC 3500 terbawa keluar oleh bufer yang mengandung $\mathrm{NaCl}$ (Abeyrathne et al., 2014; Wolman et al., 2010). Hasil SDS-PAGE membuktikan bufer $0,1 \mathrm{M}$ glisin- $\mathrm{NaOH} \mathrm{NaCl} 0,5 \mathrm{M}$ pada $\mathrm{pH} 8,9$ dan 10 dapat memisahkan lisozim pada BM 14,4 kDa (Gambar 2, GN8, GN9 dan GN10) walaupun masih terlihat protein yang lain (ovalbumin, ovotransferin, ovomucoid dan ovomucin) dengan konsentrasi yang sangat rendah. Hasil analisis dengan software imageJ (Gambar 4) menunjukkan kemurnian lisozim yang didapatkan pada kisaran $43,72-68,62 \%$.

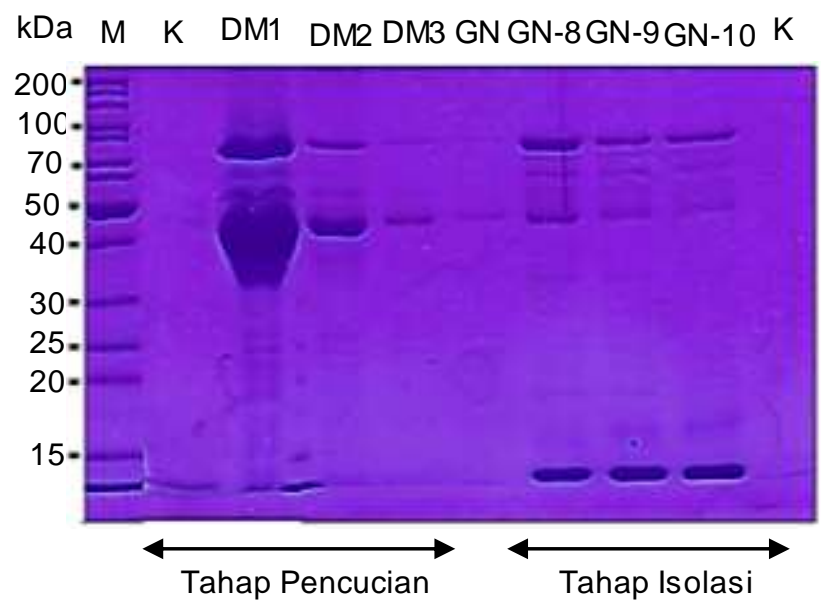

Keterangan: $\mathrm{K}=$ kosong; DM1 = Bilasan akuades steril ke1, $M=$ markers; DM2= Bilasan akuades steril ke-2, $\mathrm{DM}=$ Bilasan akuades steril ke-3; $\mathrm{GN}=$ Bufer $0.1 \mathrm{M}$ glisin-NaOH pH8; GNN-8=0.1 M Bufer Glisin- $\mathrm{NaOH}$ $\mathrm{pH} 8 \mathrm{NaCl} 0,5 \mathrm{M}$; GNN-9=0,1 M Bufer Glisin- $\mathrm{NaOH}$ pH $9 \mathrm{NaCl} 0,5 \mathrm{M}$; GNN-10=0,1 M Bufer Glisin- $\mathrm{NaOH}$ $\mathrm{pH} 10 \mathrm{NaCl} 0,5 \mathrm{M}$

Gambar 2. Hasil SDS-PAGE isolasi albumin telur ayam ras dengan metode preparatif

Penelitian Ludin et al. (2011) menghasilkan tingkat kemurnian $72-96 \%$ lisozim dengan menggunakan cryogel penukar kation. Nilai pada riset ini lebih rendah dibandingkan dengan penelitian Luding et al. (2011) disebabkan resin dan bufer yang digunakan berbeda. 


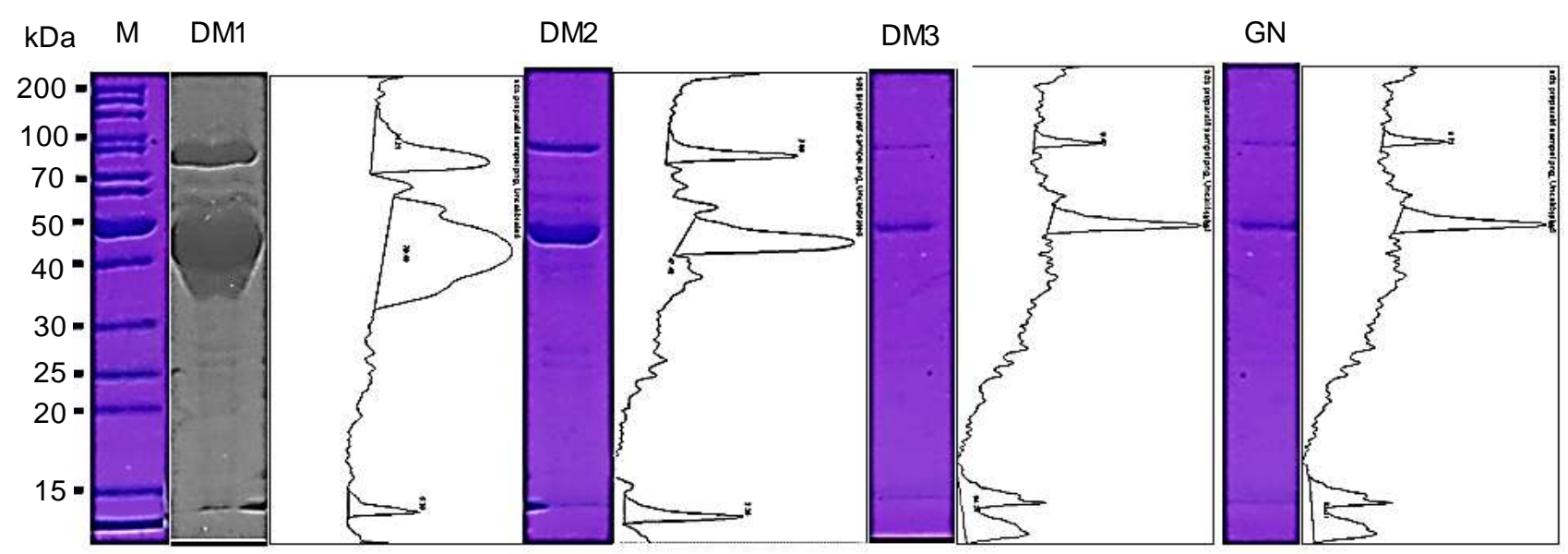

Gambar 3. Hasil SDS-PAGE isolasi lisozim albumin telur ayam ras dengan metode preparatif pada tahap pencucian dengan pengukuran kemurnian menggunakan software imageJ 14.7 (Wayne $\mathrm{NIH}$ USA, 2017)

Tabel 2. Konsentrasi protein lisozim hasil purifikasi dengan metode preparatif (metode lowry)

\begin{tabular}{|c|c|c|c|c|}
\hline No. & Tahapan Reaksi & $\begin{array}{c}\text { Kons entrasi Protein } \\
(\mathrm{mg} / \mathrm{mL})\end{array}$ & $\begin{array}{l}\text { Total Protein } \\
(\mathrm{mg})\end{array}$ & $\begin{array}{c}\text { Rendemen } \\
(\%)\end{array}$ \\
\hline \multirow[t]{3}{*}{1} & $\begin{array}{l}\text { Pencucian protein selain lisozim } \\
\text { a. Tahap 1, pencucian dengan akuades }\end{array}$ & $1,61 \pm 0,02$ & 56,35 & 0,27 \\
\hline & $\begin{array}{l}\text { b. Tahap 2, pencucian dengan akuades } \\
\text { c. Tahap 3, pencucian dengan akuades }\end{array}$ & $\begin{array}{l}0,50 \pm 0,04 \\
0,18 \pm 0,00\end{array}$ & $\begin{array}{l}5,00 \\
0,90\end{array}$ & $\begin{array}{l}0,02 \\
0,00\end{array}$ \\
\hline & $\begin{array}{l}\text { d. Tahap 4, pencucian dengan bufer } 0,1 \mathrm{M} \text { glisin- } \\
\mathrm{NaOH} \mathrm{pH} 8\end{array}$ & $0,07 \pm 0,00$ & 0,53 & 0,00 \\
\hline \multirow{4}{*}{$\pi$} & Total protein tahap pencucian & & 62,78 & 0,29 \\
\hline & $\begin{array}{l}\text { Isolasi Lis ozim } \\
\text { a. Bufer } 0,1 \mathrm{M} \text { glisin- } \mathrm{NaOH} \text { pH } 8+0,5 \mathrm{M} \mathrm{NaCl}\end{array}$ & $0,74 \pm 0,04$ & 18,50 & 0,09 \\
\hline & $\begin{array}{l}\text { b. Bufer } 0,1 \mathrm{M} \text { glisin- } \mathrm{NaOH} \text { pH } 9+0,5 \mathrm{M} \mathrm{NaCl} \\
\text { c. Bufer } 0,1 \mathrm{M} \text { glisin- } \mathrm{NaOH} \text { pH } 10+0,5 \mathrm{M} \mathrm{NaCl}\end{array}$ & $\begin{array}{l}1,26 \pm 0,02 \\
1,48 \pm 0,03\end{array}$ & $\begin{array}{l}50,40 \\
70,30\end{array}$ & $\begin{array}{l}0.24 \\
0,33\end{array}$ \\
\hline & Total protein tahap isolasi & & 139,20 & 0,66 \\
\hline
\end{tabular}

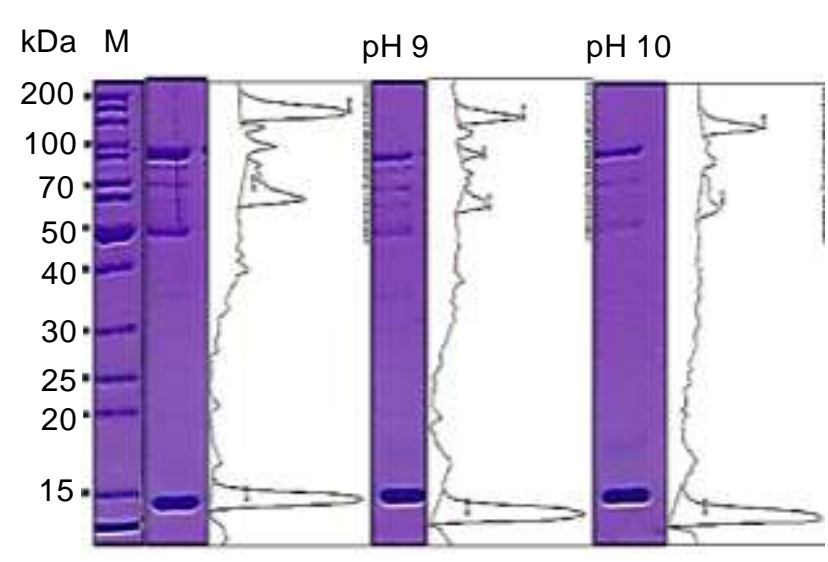

Gambar 4. Hasil SDS-PAGE isolasi lisozim albumin telur ayam ras dengan metode preparatif pada tahap isolasi dengan pengukuran kemurnian menggunakan software imageJ 14.7 (Wayne $\mathrm{NIH}$ USA, 2017)
Tahapan isolasi menggunakan bufer $0,1 \mathrm{M}$ glisin- $\mathrm{NaOH}$ pH8 $0,5 \mathrm{M} \mathrm{NaCl}$ menghasilkan protein dengan konsentrasi $0,74 \mathrm{mg} / \mathrm{mL}$ dengan kemurnian lisozim sebesar $43,72 \%$. Pada tahap berikutnya dengan bufer yang sama pH 9 menghasilkan protein dengan konsentrasi $1,26 \mathrm{mg} / \mathrm{mL}$ dengan kemurnian lisozim sebesar $66,76 \%$. Tahap terakhir dari isolasi menghasilkan protein dengan konsentrasi $1,48 \mathrm{mg} /$ $\mathrm{mL}$ dengan kemurnian lisozim sebesar $68,62 \%$. Kisaran konsentrasi protein pada tahap isolasi lisozim 0,74-1,48 $\mathrm{mg} / \mathrm{mL}$ dengan kisaran kemurnian 43,72$68,62 \%$.

Total protein terlarut yang didapat pada tahap pencucian sebesar $62,78 \mathrm{mg}$ dengan total rendemen $1,25 \%$. Pada tahap isolasi didapat total protein sebesar $139,2 \mathrm{mg}$ dengan total rendemen 2,78\%. Protein terlarut yang lain (selain lisozim) banyak terbuang di supernatan pada saat tahap pemisahan pertama (tahap sentrifugasi $3400 \mathrm{~g}, 20$ menit, $4^{\circ} \mathrm{C}$ ).

Berdasarkan data tahap terakhir (bufer $0,1 \mathrm{M}$ glisin- $\mathrm{NaOH}$ pH $100,5 \mathrm{M} \mathrm{NaCl}$ ) dengan kemurnian lisozim mencapai $68,62 \%$, dapat disimpulkan masih banyak lisozim yang terikat di resin. Berdasarkan 
perhitungan secara teori, total lisozim yang dapat diisolasi dari tahap ini sebesar $630,99 \mathrm{mg}$, akan tetapi yang didapat hanya 139,20 mg lisozim, 20\% dari nilai yang seharusnya didapat. Oleh sebab itu perlu tahapan elusi untuk membawa lisozim dari resin. Tahapan elusi pada resin dilakukan pada penelitian selanjutnya dengan jumlah sampel yang lebih besar.

Hasil penelitian Geng et al. (2012) dengan metode isolasi dan purifikasi dua tahapan, yaitu Polietilen glikol (PEG) dilanjutkan dengan $Q$ sepharose (kromatografi penukar kation) menghasilkan rendemen $30 \%$ dari nilai total lisozim yang seharusnya didapat dengan kemurnian $86,7-91,2 \%$. Nilai pada riset ini lebih rendah dibandingkan dengan penelitian Geng et al. (2012) disebabkan metode, resin dan bufer yang digunakan berbeda.

\section{Hasil isolasi lisozim telur ayam ras dengan me- tode analitik}

Selain dengan cara preparatif, isolasi lisozim dilakukan juga secara analitik. Pengertian analitik disini adalah volume sampel yang diisolasi jauh lebih kecil dibandingkan dengan cara preparatif. Volume sampel yang diisolasi dengan cara preparatif sebesar $205 \mathrm{~g}$ sedangkan dengan cara analitik sebesar $3,16 \mathrm{~g}(1,5 \%$ dari volume sampel metode preparatif). Kromatogram pemisahan pada absorbansi $280 \mathrm{~nm}$ dapat dilihat pada Gambar 5. Pada fraksi awal pada tahap pencucian, nilai absorbansi tinggi kemudian menurun sampai fraksi ke-8. Pada fraksi 2 terlihat konsentrasi protein terlarut sebesar $4,72 \mathrm{mg} / \mathrm{mL}$ dengan perhitungan rendemen sebesar 7,28\% (Tabel 3). Protein yang tertampung ini sebagian besar merupakan protein ovalbumin (54\%, PI 4,5, BM 45kD), ovotransferin (12\%, PI 6, BM 76kD), ovomucoid (11\%, PI 4,1, BM 28kD) dan ovomucin (3,5\%, PI 4,5-5). Hasil elektroforesis SDS-PAGE (Gambar 6, F5, F6) pada fraksi kedua dan kelima masih terlihat semua protein albumin. Pada fraksi ke-8 (Gambar 5 dan 6), protein yang muncul pada elektroforesis SDS-PAGE mulai berkurang. Fraksi ke-16 terdeteksi, protein terlarut sebesar $0,20 \mathrm{mg} / \mathrm{mL}$ dan berada pada kisaran yang sama sampai dengan fraksi ke18. Protein ini dengan konsentrasi sebesar 0,25 $\mathrm{mg} / \mathrm{mL}$ sebagian besar hanya tersusun oleh lisozim berdasarkan hasil elektroforesis SDS-PAGE. Konsentrasi protein tersebut selanjutnya menurun sampai dengan fraksi terakhir (fraksi ke-30). Pada fraksi ke-25, pita untuk protein lisozim mulai tidak terlihat, hal ini berarti konsentrasi lisozim yang terdapat pada fraksi sangat kecil, yaitu $0,02 \mathrm{mg} / \mathrm{mL}$.

Pada penelitian ini, $\mathrm{pH}$ yang digunakan adalah $\mathrm{pH}$ 9,3 berbeda dengan metode preparatif yang menggunakan tiga $\mathrm{pH}$ yang berbeda pada tahap isolasinya. Ketika resin amberlite FPC 3500 diekulibrasi pada $\mathrm{pH}$ ini, diyakini gugus karboksilat pada resin ini mengalami deprotonasi yang mengakibatkan resin bermuatan negatif. Sementara, lisozim akan bermuatan positif pada $\mathrm{pH}$ 9,3 karena titik isoelektrik (pl) protein ini adalah 10,7. Perbedaan muatan antara lisozim dan resin memungkinkan kedua group tersebut berikatan secara ionik. Berdasarkan penelitian Abeyrathne et al. (2014) pH 9,3 merupakan $\mathrm{pH}$ yang paling optimal untuk isolasi lisozim dengan resin amberlite FPC 3500.

Luding et al. (2011) menyatakan kemurnian lisozim berdasarkan hasil perhitungan dengan SDSPAGE sebesar $70-96 \%$. Konsentrasi $\mathrm{NaCl}$ yang rendah pada bufer digunakan untuk melepaskan ikatan lisozim yang lemah, semakin kuat ikatan lisozim dengan resin, semakin tinggi konsentrasi $\mathrm{NaCl}$ yang dibutuhkan untuk melepaskan ikatan tersebut. Konsentrasi $\mathrm{NaCl}$ pada bufer fosfat $(\mathrm{pH} 7,8)$ merupakan faktor yang sangat penting dalam isolasi dan purifikasi lisozim. Perbedaan konsentrasi $\mathrm{NaCl}$ juga dilakukan pada isolasi lisozim dengan metode analitik.

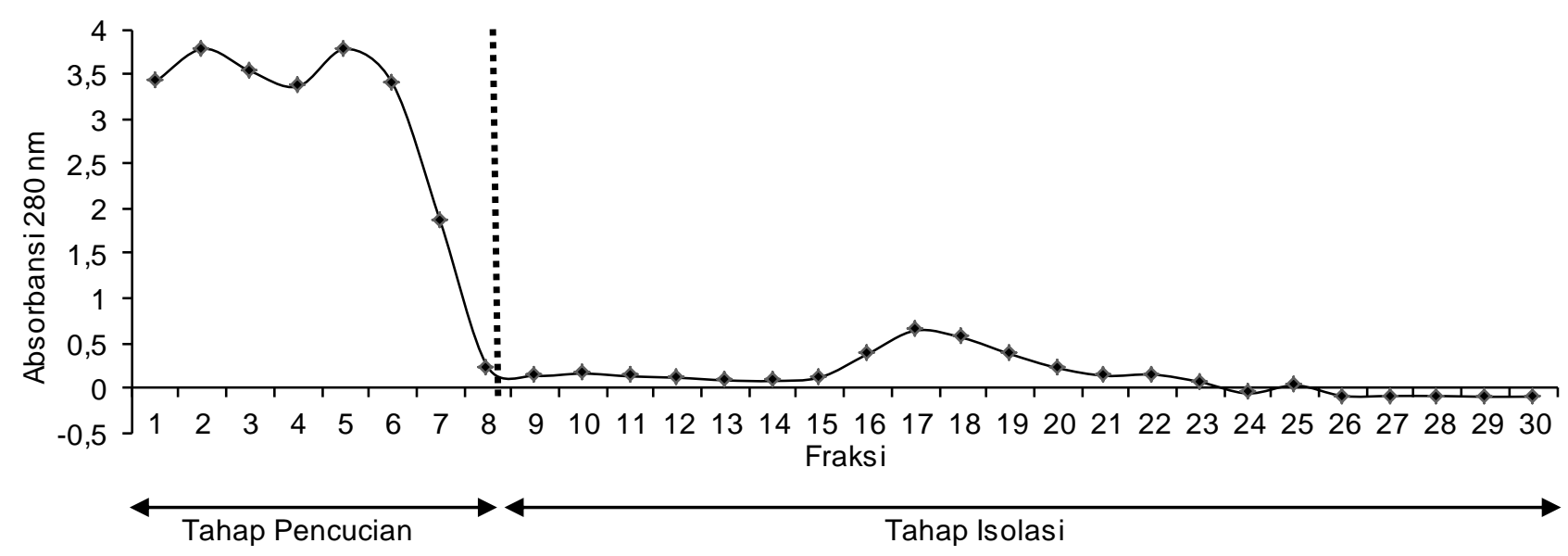

Gambar 5. Hasil isolasi lisozim secara analitik dimonitor dengan pengukuran pada panjang gelombang 280 $\mathrm{nm}$ 
Densitas masing-masing pita hasil pemisahan dihitung, berdasarkan densitas ini selanjutnya persentase puncak pada elektroforesis dapat dihitung secara kuantitatif. Persentase kemurnian lisozim dari $48,9 \%$ pada fraksi 16 menjadi $63,03 \%$ pada fraksi ke 25 . Kisaran konsentrasi protein dari fraksi ke-16 sampai dengan ke-25 adalah 0,02-0,25 mg/ $\mathrm{mL}$. Fraksi-fraksi berikutnya juga ternyata mengandung lisozim meskipun dengan konsentrasi lebih sedikit. Hal ini menunjukkan ikatan lisozim dengan resin tidak homogen. Fraksi-fraksi yang terelusi lebih dulu merupakan fraksi dengan lisozim yang berikatan lebih lemah dengan resin. Konsekuensinya, konsentrasi $\mathrm{NaCl}$ yang diperlukan untuk melepas ikatan tersebut lebih sedikit dibandingkan dengan fraksifraksi yang terelusi setelahnya. Semakin meningkat waktu elusi (elution time) semakin tinggi konsentrasi $\mathrm{NaCl}$ yang digunakan. Menarik untuk diperhatikan bahwa beberapa kontaminan protein masih terlihat di fraksi-fraksi yang mengandung lisozim, meskipun dengan jumlah yang sangat sedikit (minor). Berdasarkan ukuran, protein-protein tersebut diyakini bukan avidin, melainkan jenis protein lain dari putih telur. Meskipun secara teoritis protein-protein tersebut tidak memungkinkan untuk berikatan dengan resin karena muatan yang sama, akan tetapi hasil pada Gambar 6,7 dan 8 menunjukkan bahwa ikatan resin dengan protein-protein tersebut masih terjadi, meskipun secara magnitude tidak begitu besar. Hal ini disebabkan beberapa hal, antara lain: pengikatan terjadi bukan secara kimia, melainkan secara fisik (entrapment) oleh resin. Alternatif lainnya adalah, sifat kimia protein tersebut tidak homogen yang memungkinkan beberapa molekul dari populasi protein tersebut masih bisa berikatan secara ionik dengan resin.

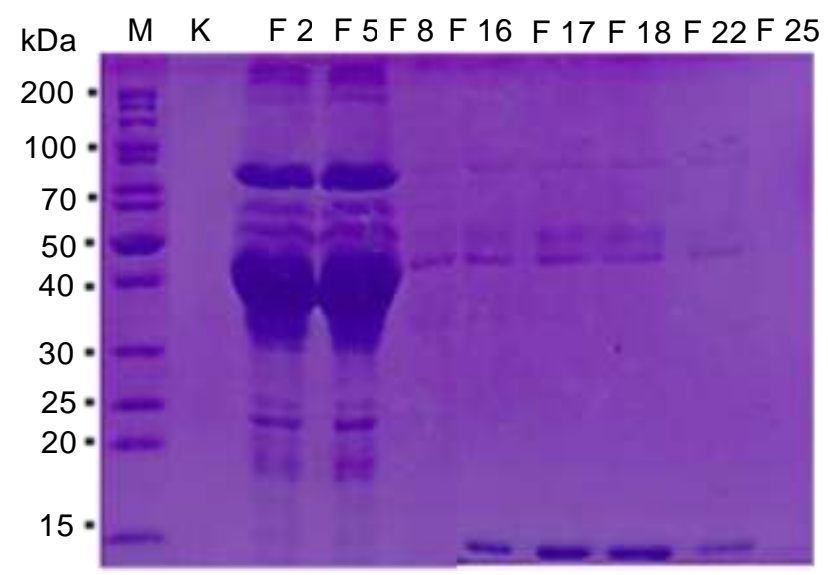

Keterangan: F2= Fraks $i$ ke- 2 dan seterusnya; $\mathrm{M}=$ markers

Gambar 6. Hasil SDS-PAGE isolasi lisozim albumin telur ayam ras dengan metode analitik (Abeyrathne et al., 2013; Abeyrathne et al., 2014) dengan dengan perbedaan $\mathrm{pH}$ glisin $\mathrm{NaOH}$

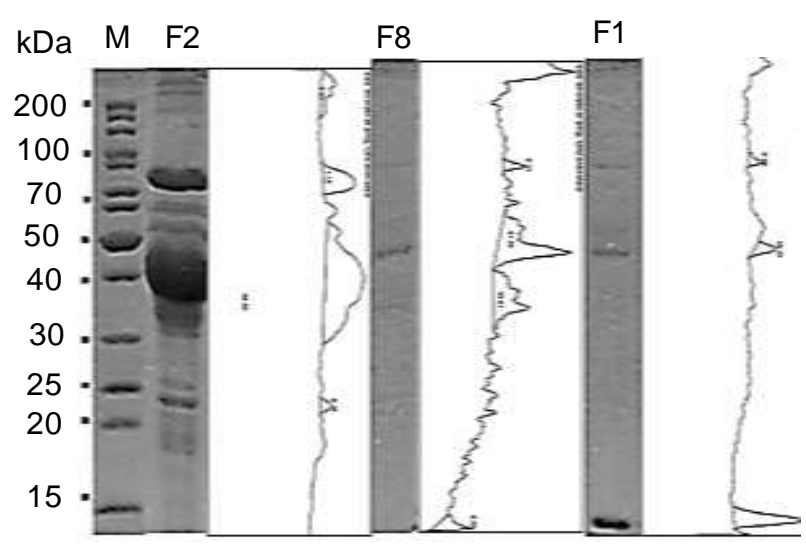

Gambar 7. Hasil SDS-PAGE isolasi lisozim albumin telur ayam ras dengan metode analitik pada tahap pencucian dengan pengukuran kemurnian menggunakan software imageJ 14.7 (Wayne $\mathrm{NIH}$ USA, 2017)

Meskipun demikian, secara umum teknik purifikasi satu tahap ini sudah berhasil mengisolasi lisozim dari telur ayam ras dengan tingkat kemurnian lebih dari $63 \%$. Tingkat kemurnian ini cukup untuk digunakan dalam beberapa uji biokimia selanjutnya. Perlu dicatat juga bahwa proses kromatografi dilakukan secara manual. Elusi fraksi tidak dilakukan secara otomatis dengan HPLC atau FPLC. Ketidakseragaman kecepatan aliran dan tekanan pada setiap tahap sangat memungkinkan untuk terjadi sehingga kemurniannya tidak sebagus jika dibandingkan dengan proses otomasi. Akan tetapi dengan hasil yang didapat ini, teknik ini bisa digunakan dalam prosesproses berikutnya untuk mengisolasi lisozim dari telur ayam dengan lebih sederhana dan tetap menghasilkan protein dengan kemurnian yang bisa diterima.

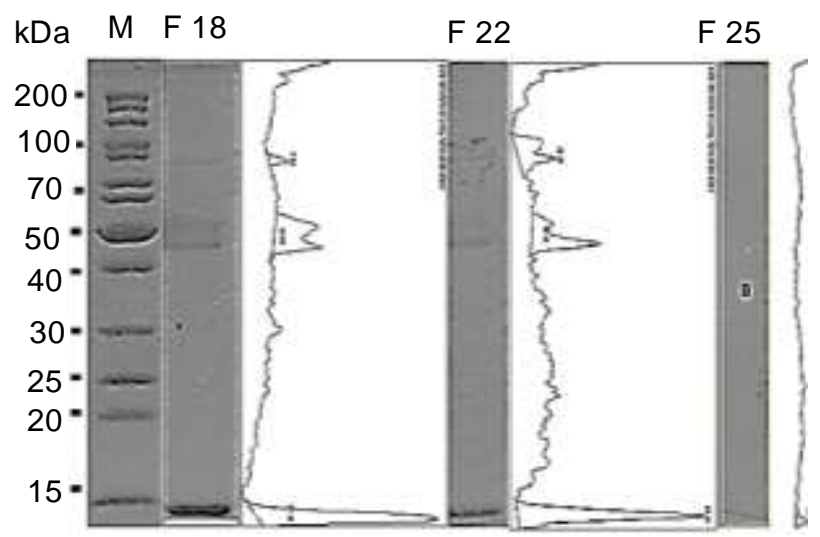

Gambar 8. Hasil SDS-PAGE isolasi lisozim albumin telur ayam ras dengan metode analitik pada tahap pencucian dengan pengukuran kemurnian menggunakan software imageJ 14.7 (Wayne $\mathrm{NIH}$ USA, 2017) 
Geng et al. (2012) dengan metode isolasi dan purifikasi dua tahapan, yaitu polietilen glikol (PEG) dilanjutkan dengan $Q$ sepharose (kromatografi penukar kation) berhasil memisahkan beberapa protein putih telur, yaitu ovalbumin, ovomucin, ovotransferin, ovoflavoprotein dan lisozim. Hasil isolasi dan purifikasi lisozim menghasilkan rendemen 30\% dari nilai total lisozim yang seharusnya didapat dengan kemurnian $86,7-91,2 \%$.

Rendemen fraksi ke-2 lebih besar dibandingkan dengan yang lain, hal ini disebabkan protein yang ada tidak hanya lisozim. Rendemen lisozim yang tertinggi didapat pada fraksi ke-18, sebesar $0,39 \%$. Fraksi berikutnya menghasilkan rendemen yang semakin kecil, hal ini disebabkan jumlah lisozim yang terikat pada kolom amberlite FPC 3500 semakin berkurang. Kekurangan dari metode ini sampel yang akan diisolasi dibatasi oleh panjang kolom. Kolom yang digunakan dengan volume $50 \mathrm{~mL}$, diisi dengan resin $25 \mathrm{~mL}$, maksimal volume sampel $30 \mathrm{~mL}$. Albumin memiliki viskositas yang cukup besar, sehingga sampel harus diencerkan sebesar 10x volume sampel, hal ini dilakukan untuk mencegah berhentinya sampel di resin.

\section{KESIMPULAN}

Isolasi lisozim ayam ras dapat dilakukan dengan menggunakan resin penukar ion, amberlite FPC 3500. Kelemahan isolasi lisozim secara analitik adalah jumlah sampel yang lebih kecil dibandingkan isolasi lisozim secara preparatif, yaitu 1,5\% dari sampel isolasi secara preparatif. Kemurnian lisozim terisolasi dari pemisahan preparatif adalah $68,62 \%$ dan kemurnian lisozim terisolasi dari pemisahan analitik adalah $63,03 \%$. Isolasi lisozim secara preparatif lebih menguntungkan, hal ini disebabkan jumlah sampel yang diisolasi lebih banyak sehingga hasil lisozimnya akan lebih banyak. Saran dari penelitian ini adalah perlu ada tahapan elusi lanjut untuk menarik lisozim yang masih terikat pada amberlite FPC 3500 .

\section{UCAPAN TERIMAKASIH}

Terimakasih diucapkan kepada Direktorat Riset dan Pengabdian Masyarakat Direktorat Jenderal Penguatan Riset dan Pengembangan, Kementerian Riset Teknologi dan Pendidikan Tinggi Republik Indonesia atas biaya yang telah diberikan untuk penelitian ini melalui Beasiswa Program Pascasarjana tahun 2012-2016 dan hibah Penelitian Strategis Nasional 2014/2015 dan D.Uk.Ahn, Department of Animal Science, lowa State University, Ames 50010; atas korespondensi yang telah diberikan.

\section{DAFTAR PUSTAKA}

Abeyrathne NS, Lee HY, Ahn DU. 2013. Sequential separation of lysozyme and ovalbumin from chicken egg white. Korean J Food Sci An 33: 501-507. DOI: 10.5851/kosfa.2013.33.4.501.

Abeyrathne NS, Lee HY, Ahn DU. 2014. Sequential separation of lysozyme, ovomucin, ovotransferrin, and ovalbumin from egg white. Poultry Sci 93: 1001-1009. DOI: 10.3382/ps.2013-03403.

Asoodeh A, Yazdi MM, Chamani J. 2012. Purification and characterisation of angiotensin I converting enzyme inhibitory peptides from lysozyme hydrolysates. Food Chem 131: 291-295. DOI: 10.1016/j.foodchem.2011.08.039.

Datta D, Bhattacharjee S, Nath A, Das R, Bhattacharjee C, Datta S. 2009. Separation of ovalbumin from chicken egg white using twostage ultrafiltration technique. Sep Purif Technol 66: 353-361. DOI: 10.1016/j.seppur.2008. 12.016

Depamede SN, Asri N, Julisaniah NI, Suryadi BF, Kisworo D. 2012. Isolation and partial purification of lysozyme from saliva of Bali cattle (Bos sondaicus) using an aqueous mixture of polyethylene glycol (PEG) with sodium sulfate. Afr J Biotechnol 11: 1977-1980. DOI: 10.5897/AJB1 1.2529.

Ding Z, Li S, Cao X. 2014. Separation of lysozyme from salted duck egg white by affinity precipitation using $\mathrm{pH}$-responsive polymer with an L-thyroxin ligand. Sep Purif Technol 138: 153-160. DOI: 10.1016/j.seppur.2014.10.021.

Direktorat Jenderal Peternakan dan Kesehatan Hewan. 2017. Populasi dan Produksi Peternakan di Indonesia. http://www.pertanian.go.id/Indika tor/tabel-4-pop-prod-nak.pdf [24 Agustus 2017].

Ercan D, Demirci A. 2014. Recent advances for the production and recovery methods of lysozyme. Crit Rev Biotechnol 36: 1078-1088. DOI: 10.310 9/07388551.2015.1084263.

Forabosco F, Löhmus M, Rydhmera L, Sundström LF. 2013. Genetically modified farm animals and fish in agriculture - a review. Lives Sci 153: 1-9. DOI: 10.1016/j.livsci.2013.01.002.

Geng F, Huang Q, Wu X, Ren G, Shan Y, Jin G, Ma M. 2012. Co-purification of chicken egg white proteins using polyethylene glycol precipitation and anion-exchange chromatography. Sep Purif Technol 96: 75-80. DOI: 10.1016/j.seppur.2012. 05.021.

Ide N, Sato E, Ohta K, Masuda T, Kitabatake N. 2009. Interactions of the sweet-tasting proteins thaumatin and lysozyme with the human sweet- 
taste receptor. J Agric Food Chem 57: 58845890. DOI: $10.1021 / \mathrm{jf} 803956 f$.

Laemmli UK. 1970. Cleavage of structural proteins during the assembly of the head of bacteriophage T4. Nature 227: 680-685. DOI: 10.1038/227 680a0.

Li-Chan ECY, Powrie WD, Nakai S. 2014. The chemistry of eggs and egg products. In: Stadelmann WJ and Cotterill OJ $4^{\text {th }}$ edition (Ed). Egg Science and Technology. 105-175. Food Product Press, New York.

Li J, Si Y, Zhao C, He J, Sun G, Huang Y. 2017. Spontaneous and efficient adsorption of lysozyme from aqueous solutions by naturally polyanion gel beads. Mater Sci Eng 76: 130-138. DOI: $10.1016 /$ j.msec.2017.03.092.

Lowry $\mathrm{OH}$, Rosebrough NJ, Farr AL, Randall RJ, 1951. Protein measurement with the folin phenol reagent. J Biol Chem 193: 265-275.

Luding Y, Shaochuan S, Junxian Y, Kejian Y. 2011. Isolation of Lysozyme from Chicken egg white using polyacrylamide-based cation-exchange cryogel. Chinese J Chem Eng 19: 876-880. DOl: 10.1016/S1004-9541(11)60068-2.

Naknukool S, Hayakawa S, Sun Y, Ogawa M. 2008. Structural and physicochemical characteristics of novel basic proteins isolated from duck egg white. Biosci, Biotechnol, Biochem 72: 20822091. DOI: $10.1271 / \mathrm{bbb} .80178$.

Rao S, Sun J, Liu Y, Zeng H, Su Y, Yang Y. 2012. ACE inhibitory peptides and antioxidant peptides derived from in vitro digestion hydrolysate of hen egg white lysozyme. Food Chem 13: 1245-1252. DOI: 10.1016/j.foodchem.2012.05. 059.

Safarik I, Sabatkova Z, Tokar O, Safarikova M. 2007. Magnetic cation exchange isolation of lysozyme from native hen egg white. Food Technol Biotechnol 45: 355-359.

Thammasirirak S, Pukcothanung $Y$, Preecharram S, Daduang S, Patramanon R, Fukamizo T, Araki T. 2010. Antimicrobial peptides derived from goose egg white lysozyme. Comp Biochem Phys C 151: 84-91. DOI: 10.1016/j.cbpc.2009. 08.009 .

Yazdi MM, Asoodeh A, Chamani J. 2012a. A novel antioxidant and antimicrobial peptide from hen egg white lisozim hydrolysates. J Funct Foods 4: 278-286. DOI: 10.1016/j.jf.2011.12.004.

Yazdi MM, Asoodeh A, Chamani J. 2012b. Structure and ACE-inhibitory activity of peptides derived from hen egg white lysozyme. Int J Peptide Res Ther 18: 353-360. DOI: 10.1007/s10989-0129311-2.

Wayne Rasband. 2017. Software ImageJ 14.7. National Institute of Mental Health, Bethesda, Maryland, USA.

Wolman FJ, Copello GJ, Mebert AM, Targounik AM, Miranda MV, Navarro del Cañizo AA, Díaz LE, Cascone O. 2010. Egg white lysozyme purification with a chitin-silica-based affinity chromatographic matrix. Eur Food Res Technol 231: 181-188. DOI: 10.1007/s00217-010-1263-1. 